\title{
PHENOMENON OF TEXT NECK IN HIGHER EDUCATION STUDENTS
}

\author{
Nikolenko Evgene, Adamovych Iryna, Vovk Kira
}

Mail for correspondence: i.adamovich@karazin.ua

\begin{abstract}
Summary: In the modern world almost all young people use smartphones and now most of the time using mobile phones belongs to additional functions. Regrettably, consequences for the musculokeletal system are not considered. It is a known fact that long-term use of the gadgets causes excessive cervical spine bending, improper posture and the formation of muscular-tonic syndrome accompanied by the pain and discomfort that is so-called "Text neck" syndrome.

The aim of the research was to study the impact of using gadgets on the formation pain syndrome in the neck and shoulders, as well as headache.

The research involved 90 respondents, 60 female and 30 males, the age of the participants was in a range from 18 to 28 years old. Using a self-created questionnaire, applying in Google docs, Text neck symptoms such as headache, pain/discomfort in the neck and shoulder, as well as awareness of this phenomenon have been evaluated.

The study has shown the primary role of the shoulder pain/discomfort among respondents, thus 59 (66\%) of the participants suffer from shoulder pain/discomfort in different degrees with the gender distribution as follows: 46 women (76\%) and 13 men (43\%). Headache was noted by 56\% of the participants and $50 \%$ suffer from neck pain/discomfort. The average phone usage time was 5.3 hours.

Only one third (32\%) of respondents associated their symptoms with the use of gadgets, so the study has demonstrated low awareness about this syndrome among students. Young people do not realize devastating impact of the gadgets on the health condition, in particular musculoskeletal system.

Thus, the authors believe that an integrated approach is needed on the part of the family, educational establishments and health care with a view to build awareness in young people and prevent Text neck formation. Seems like a reasonable implementation of the course on the possible impact of excessive gadgets use on the health condition of the students at higher education institutions.
\end{abstract}

Key words: students, Text neck, poor posture

Information about author

Nikolenko Evgene, MD, PhD, Full Prof. Head of the Department of General Practice-Family Medicine, School of Medicine, N.V. Karazin Kharkiv National University, Svobody sq., 6, Kharkiv, Ukraine, 61022

e-mail: e.nikolenko@karazin.ua https://orcid.org/0000-0002-7653-0644 Adamovych Iryna, Assistant of the Department of General Practice-Family Medicine, School of Medicine N.V. Karazin Kharkiv National University, Svobody sq., 6, Kharkiv, Ukraine, 61022 e-mail: I.adamovich@ karazin.ua https://orcid.org/0000-0002-8934-7291
Vovk Kira, PhD, Assoc. Prof. of the Department of General Practice-Family Medicine, School of Medicine, N.V. Karazin Kharkiv National University, Svobody sq., 6, Kharkiv, Ukraine ,61022 e-mail: vovkkira1970@gmail.com https://orcid.org/0000-0003-2971-0842

\section{Introduction}

Life in the modern world implies the widespread use of various devices, that undoubtedly has a lot of advantages. Almost all young people use gadgets [1], but if earlier these devices were used mainly for conversations, now most of the time using mobile phones belongs to additional functions, such as viewing social networks, chatting in messenger applications, games as well as for work purposes [2]. Nevertheless, the digital era is challenging for the modern mind as well as for the health condition and can contribute to severe health problems. If a person constantly bends one's head to look at a small screen, different problems can arise, such as a forward-head posture or a slouched, turtle-like posture and this posture induces muscle strain $[3,4,5]$.

So, widespread excessive use of mobile devices can lead to the phenomenon named "Text Neck" invented by Dr. Dean Fishman a Chiropractor in Plantation Florida. Text Neck means formation of poor posture and musculartonic syndrome caused by the frequent tilting the head downwards due to excessive texting and overuse of all handheld electronic devices [6]. Text Neck is a relatively new term but it is a common problem of the world now.

This unnatural posture could be observed earlier during reading but now it is a specially 
concerning that a forward-head posture operates on a much larger scale as a result of young people addiction to devices.

Undoubtedly, Text Neck caused not only by over-reliance of mobile phones but different types of handled devices, such as tablets, game consoles contribute to this condition.

Nevertheless, young people not always can realize that devastating effect of using their cell phones and connect their symptoms such as shoulder pain or neck pain with the excessive use of these devices.

Owing to the fact that this issue becomes extremely important different researches are carried out $[7,8,9]$. The review of Yanfei Xie et al. [10] revealed evidence for neck flexion, frequency of phone calls, texting and gaming in relation to musculoskeletal complaints among mobile device users demonstrated that the prevalence of musculoskeletal complaints in those who used mobile device varies from $1.0 \%$ to $67.8 \%$ and neck complaints were the most common with the range from $17.3 \%$ to $67.8 \%$.

According to studies by Pankti P. Samani et al. [11] of awareness of Text-neck syndrome among young-adult population living in Mumbai and Pune cities of Maharashtra, just 35\% population has heard about this term with the $8 \%$ people could figure out in this issue. Spine specialists of the Spine Institute of North America are also concerned with this phenomenon [12] and give information and tips for prevention Text neck on their website.

There are no literature sources regarding youth population in our country, therefore we consider it reasonable to investigate this issue in our endeavour.

The aim of the research was to study the impact of using gadgets on the formation pain syndrome in the neck and shoulders, as well as headache using identifying the incidence of Text neck symptoms among students of higher educational institutions.

\section{Materials and methods}

The study was performed among students of higher educational institutions. All the respondents expressed informed consent for the participation in the survey.

We figured out the connection between the amount of time spent in the front of mobile phone and the presence of the symptoms of "Text neck" through questionnaires distributed to participants.

90 subjects were included in the study with the distinction on the basis of gender as follows. 30 male $(33 \%)$ and 60 female $(67 \%)$ respondents participated in the research. The age of the responders was in a range from 18 to 28 years old.

The criteria for exclusion from the study was presence of musculoskeletal diseases, congenital cervical damages or traumas that could affect the outcome.

A self-invented questionnaire was made in Google docs. The following information was included: 1) The duration of using mobile phone daily; 2) Whether the symptoms like pain/tightness in the neck, pain/malaise in the shoulders, headache bother the participants; 3) If the students know what does it mean Text neck and connect their symptoms if the presence with the prolonged use of the cell phone.

Data analysis. Descriptive statistics was conducted to evaluate the responses obtained from the subjects. The percentage of responses for each question was calculated.

Results In the study we determined the average time of using cell phones that was 5,3 hour (from 1,5 hour up to 16 hours).

The distribution of the answers is illustrated in the figures $1-3$. Thus, $45(51 \%)$ of the participants did not suffer from pain/discomfort in the neck, $24(27 \%)$ felt pain 1-2 times monthly, 11 (12\%) 1-2 times in a week, 10 $(11 \%)$ suffered from pain with the frequency more than 3 times per week (Fig.1). 


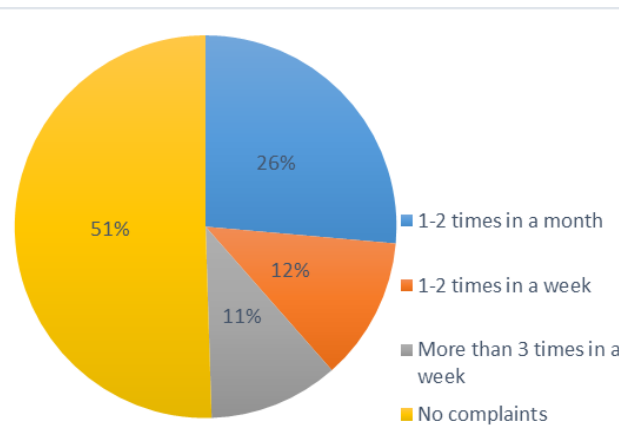

Fig. 1. Distribution of pain/discomfort in the neck among all participants

Figure 2 shows the percentage of the responders suffering from the shoulder pain//discomfort.

$31(34 \%)$ did not feel the shoulder pain. Dispersion of the frequency was as follows. 1-2 times in a month - 26 (29\%), 1-2 times in a week - $18(20 \%)$, more than 3 times per week 15

(17\%).

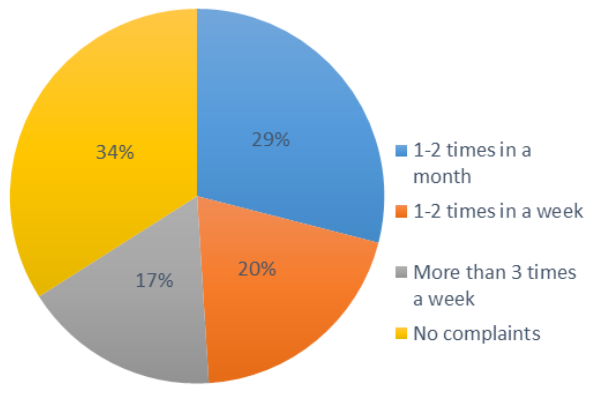

Fig.2. Distribution of shoulder pain/discomfort among all participants

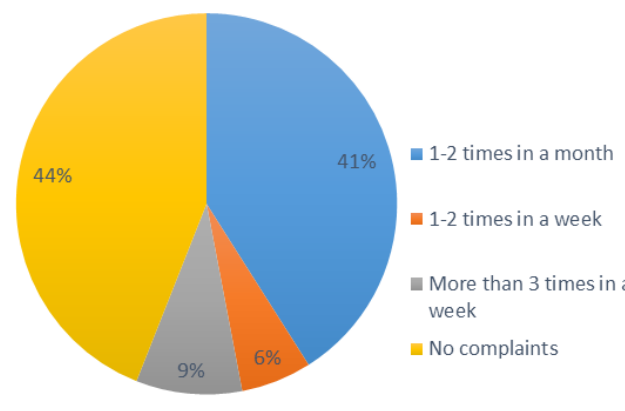

Fig. 3. Distribution of headache among all participants
Figure 3 shows spread of headache in all responders.

Neck complaints were not observed in 24 women from 60 (40\%), 3 times per week 10 (17\%), 1-2 times weekly 9 (15\%), 1-2 times in a month 17 (28\%). 24 participants did not note neck pain.

Shoulder pain or discomfort experienced in 46 women $(76 \%)$ with the following range: $1-2$ times monthly - 19 (32\%), 1-2 times per week - 13 (21\%), more than 3 times in a week - 14 (23\%). No complain - $14(24 \%)$.

Headache did not bother 22 (37\%) female participants, 1-2 time monthly - 26 (43\%), 1-2 time per week $5(8 \%)$, more than 3 times in a week $-7(12 \%)$.

In men the symptoms were distributed as follows. Neck pain/discomfort were not observed in 21 participants $(70 \%)$. No one felt pain in the neck more than 3 times per week, 1-2- times in a week $-1(3 \%), 1-2$ times monthly $-8(27 \%)$.

Shoulder pain/discomfort was the most commonly notified symptom in male participants. Thus, 17 (57\%) participants did not have this symptom. Nevertheless, 7 (23\%) noticed the pain 1-2 times monthly, 5 (17\%) 1-2 times in a week and $1(3 \%) 3$ times in a week.

The incidence of headache among male participants was as follows. No headache 17 (57\%) participants, 1-2 times in a month - 11 (37\%), 1-2 times weekly $-1(3 \%)$, more than 3 times in a week - $1(3 \%)$.

When comparing data about the symptoms of Text neck in men and women the difference is obvious. Each complaint occured more frequently in female participants (Fig. 4-6).

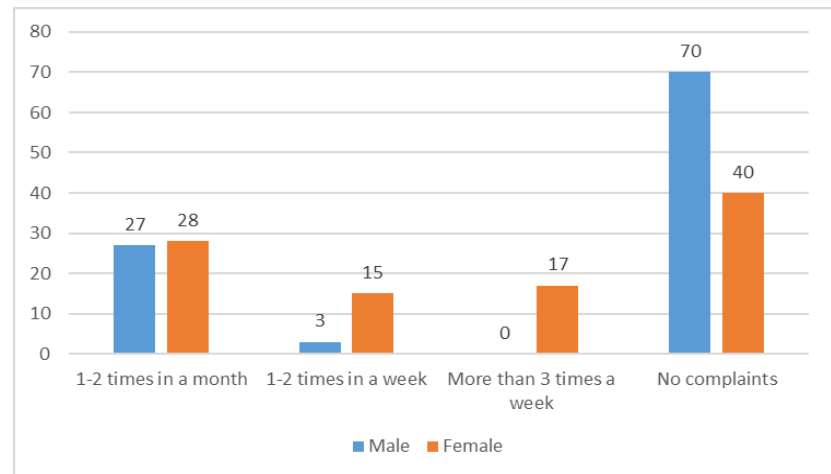

Fig. 4. Comparison the incidence rate of neck pain/discomfort in male and female 


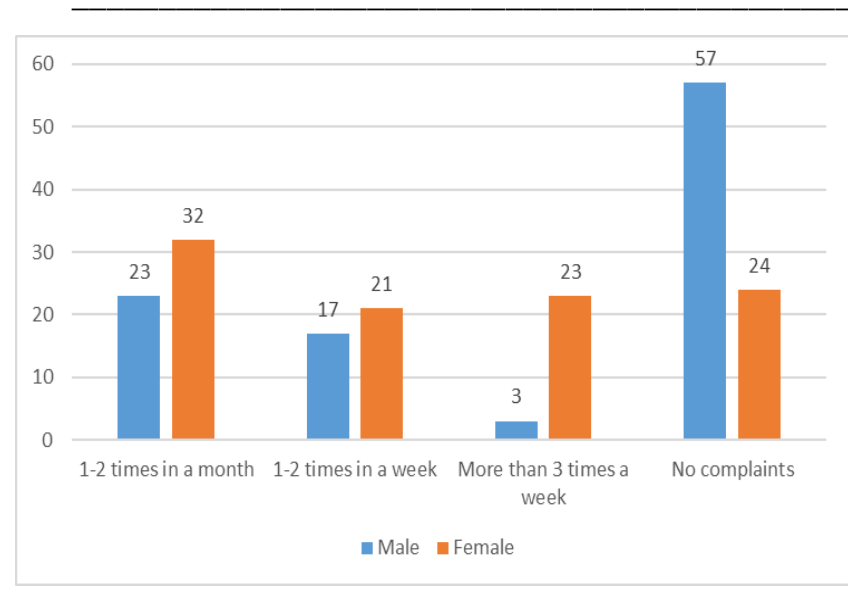

Fig. 5. Comparison the incidence rate of shoulder pain/discomfort in male and female

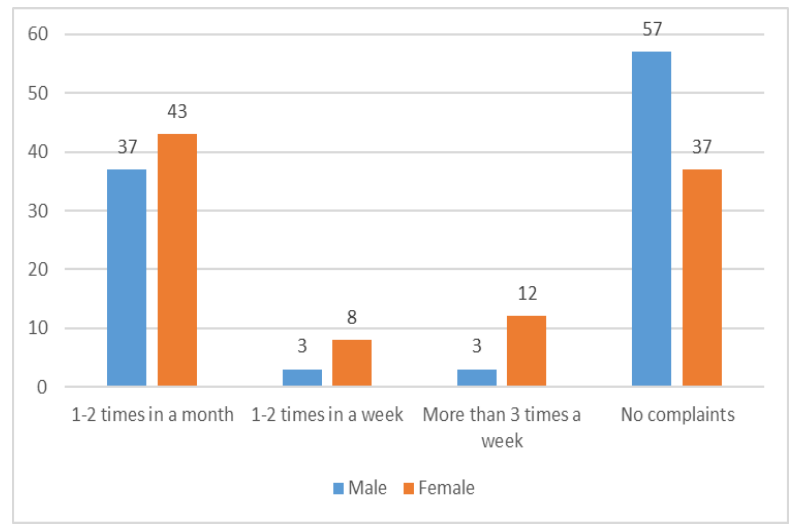

Fig. 6. Comparison the incidence rate of headache in male and female

When interviewed about the knowledge of Text neck just $23 \%$ of responders knew about this phenomenon (Fig. 7) and 32\% connected their symptoms with overuse of smartphone (Fig.8).

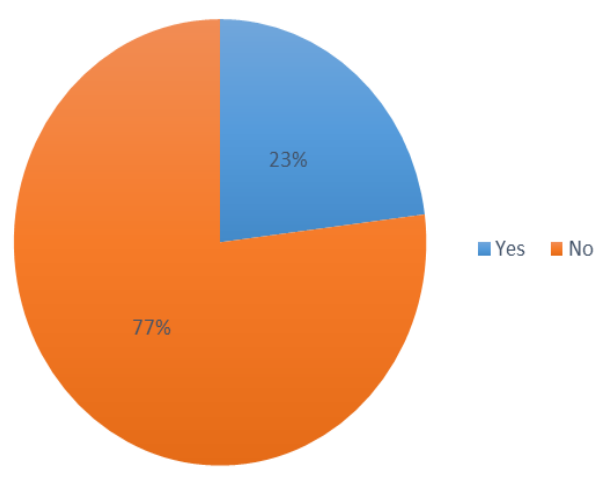

Fig. 7. Awareness of Text neck among responders

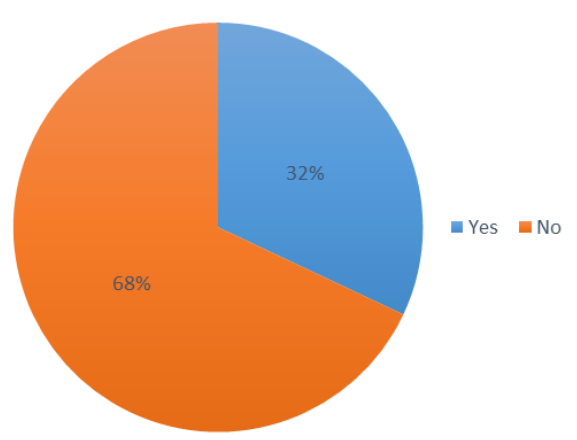

Fig. 8. Connection the symptoms with overuse of cell phone

\section{Conclusion}

1.The study has shown the primary role of the shoulder pain/discomfort among respondents, thus $59(66 \%)$ of the participants suffer from shoulder pain/discomfort in different degrees with the gender distribution as follows: 46 women $(76 \%)$ and 13 men $(43 \%)$.

2.One third of respondents associated their symptoms with the use of gadgets.

Young people do not realize devastating impact of the gadgets on the health condition, in particular musculoskeletal system. We are of the opinion that development of new more flexible questionnaires for identifying risk factors and prevention of this phenomenon is prospectively.

3.An integrated approach is needed on the part of the family, educational establishments and health care with a view to build awareness in young people and prevent Text neck formation. We consider it reasonable to introduce course on the gadgets' impact on the health condition of the students at higher education institutions of Ukraine.

\section{References}

1. Toh SH, Howie EK, Coenen P, Straker LM. "From the moment I wake up I will use it...every day, very hour": a qualitative study on the patterns of adolescents' mobile touch screen device use from adolescent and parent perspectives. BMC Pediatr. 2019 Jan 24;19(1):30. DOI: 10.1186/s12887-019-13995

2. Lauricella AR, Cingel DP, Blackwell $\mathrm{C}$ et al. The mobile generation: youth and adolescent ownership and use of new media. Comm Res. Rep. 2014;31(4):357-364. DOI:10.1080/08824096.2014.963221

3. Lee S, Lee D, Park J. Effect of the cervical flexion angle during smart phone use on muscle fatigue of the cervical erector spinae and upper trapezius. J Phys Ther Sci. 2015 Jun; 27(6): 18471849. doi: $10.1589 /$ jpts. 27.1847 
4. Namwongsa S, Puntumetakul R, Neubert MS, Boucaut R. Effect of neck flexion angles on neck muscle activity among smartphone users with and without neck pain.

Ergonomics. 2019 Dec;62(12):1524-1533. DOI: 10.1080/00140139.2019.1661525

5. Neupane S, Ali UI, Mathew A. Text Neck SyndromeSystematic Review. Imperial $\mathbf{J}$ Interdisciplinary Res. 2017;3(7):141-8. ISSN: 2454-1362, http://www.onlinejournal.in 6. Nizar Abdul Majeed Kutty. Text neck: a global epidemic of the modern era.

MOJ Yoga \& Physical Therapy. Volume 4 Issue 1 - 2019 eISSN: 2573-2927

7. Toh SH, Coenen P, Howie EK, Straker LM. The associations of mobile touch screen device use with musculoskeletal symptoms and exposures: a systematic review. PLoS One. 2017 Aug 7; 12(8). DOI: 10.1371/journal.pone.0181220

8. Smith L, Louw Q, Crous L, Grimmer-Somers K. Prevalence of Neck Pain and Headaches: Impact of Computer Use and Other
Associative Factors. Cephalalgia. 2009 March; 29(2):250-7 DOI: 10.1111/j.1468-2982.2008.01714.x

9. Gustafsson E, Thomée S, Grimby-Ekman A, Hagberg M. Texting on mobile phones and musculoskeletal disorders in young adults: a five year cohort study. Appl ergon. 2017; 58 :20814. DOI: $10.1016 /$ j.apergo.2016.06.012

10.Xie Y, Szeto G, Dai J. Prevalence and risk factors associated with musculoskeletal complaints among users of mobile handheld devices: A systematic review. Applied ergonomics. 2017; 59:132-42. DOI: 10.1016/j.apergo.2016.08.020

11. Pankti P. Samani 1, Neeraj A. Athavale. et al. Awareness of text neck syndrome in young-adult population. Int J Community Med Public Health. 2018 Aug;5(8):3335. DOI: 10.18203/23946040.ijcmph20183057

12. Jason M. Cuéllar, Todd H. Lanman. "Text-neck": an epidemic of the modern era of cell phones? The spine journal: official journal of the North American Spine Society 17(6). March 2017 DOI: 10.1016/j.spinee.2017.03.009.

\title{
ФЕНОМЕН КОМП'ЮТЕРНОЇ ШИЇ СЕРЕД СТУДЕНТІВ ВИЩИХ НАВЧАЛЬНИХ ЗАКЛАДІВ
}

\author{
Ніколенко С. Я., Адамович І. В., Вовк К. В.
}

Пошта для листування: i.adamovich@karazin.ua

Резюме: У сучасному світі практично все молоді люди використовують гаджсети $і$ зараз більша частина часу використання мобільних телефонів належсть додатковим функиіям. На жаль, молоді люди при цььому не враховують наслідки впливуна стан опорно-рухового апарату. Відомо, що тривале використання гаджетів призводить до надмірного згинання иийного відділу хребта, неправильної постави та формування м'язово-тонічного синдрому, шео супроводжується болем та дискомфортом, тобто синдрому так званої "комп'ютерної ипі" (англ. Teхt песк).

Метою даної статті була оиінка впливу використання гаджетів на формування больового синдрому в ииї та плечах, а також головного болю в студентів вищих навчальних закладів.

У дослідженні брали участь 90 респондентів, з них 60 жіночої статі і 30 чоловічої статі, вік учасників становив від 18 до 28 років.. За допомогою самостійно створеного опитувальника в документах Gооglе очінювалися такі симптоми комп'ютерної ииї, як головний біль, біль/дискомфорт в ииї, в плечах, а такожс обізнаність про даний феномен.

Дослідження показало основну роль болю/дискомфорту в плечах серед респондентів, таким чином 59 (66\%) учасників страждають від болю/дискомфорту в плечах в різному ступені із розподілом за статтю: 46жінок (76\%) та 13 чоловіків (43\%). Головний біль в тій чи іниій мірі турбував 56\% респондентів, біль/дискомфорт в ипї відзначили 50\% учасників. В ході дослідження було визначено середній час користування телефоном молодими людьми, який склав 5,3 години.

Лиме третина (32\%) респондентів пов'язували свої симптоми із використанням гаджетів, тож дослідження продемонструвало низьку обізнаність щуодо цьього синдрому серед студентів. Молоді люди не усвідомлюють руйнівного впливу надмірного використання гаджетів на стан здоров'я, зокрема на опорно-руховий апарат.

Приймаючи до уваги вищенаведене, автори вваюсають за необхідне використовувати комплексний підхід з боку сім'і, навчальних закладів та охорони здоров'я в запобіганні розвитку даного синдрому, атакожс включити в навчальні програми курс для ознайомлення студентів з можливими негативними наслідками надмірного використання гаджетів на їхне здоров'я.

Ключові слова: студенти, комп’ютерна шия, неправильна постава

\section{Інформація про авторів}

Ніколенко Свгеній Якович, д. мед. н., проф., зав. кафедри загальної практикисімейної медицини медичного факультету Харківського національного університету імені В. Н. Каразіна, майдан Свободи, 6, м. Харків, Україна, 61022

e-mail: e.nikolenko@karazin.ua https://orcid.org/0000-0002-7653-0644
Адамович Ірина Валеріївна, асистент кафедри загальної практики-сімейної медицини медичного факультету Харківського національного університету імені В. Н. Каразіна, майдан Свободи, 6, м. Харків, Україна, 61022

e-mail: i.adamovich@karazin.ua https://orcid.org/0000-0002-8934-7291
Вовк Кіра Віталївна, к. мед. н., доц. кафедри загальної практики-сімейної медицини медичного факультету Харківського національного університету імені В. Н. Каразіна, майдан Свободи, 6, м. Харків, Україна 61022

e-mail: vovkkira1970@gmail.com https://orcid.org/0000-0003-2971-0842 


\title{
ФЕНОМЕН КОМПЬЮТЕРНОЙ ШЕИ СРЕДИ СТУДЕНТОВ ВЫСШИХ УЧЕБНЫХ ЗАВЕДЕНИЙ
}

\author{
Николенко Е. Я., Адамович И. В., Вовк К. В.
}

Пошта для листування: i.adamovich@karazin.ua

Резюме. В современном мире практически все молодые люди используют гаджеты и теперь большая часть времени использования мобильных телефонов принадлежит дополнительным функциям. $K$ сожалению, молодые люди не учитывают при этом воздействия на опорно-двигательный аппарат. Известно, что длительное использование гаджетов приводит к избыточному сгибанию шейного отдела позвоночника, неправильной осанке и формированию мылечно-тонического синдрома, который сопровождается болью и дискомфортом, то есть синдрому так называемой «компьютерной шеи» (англ. Text nесk). Целью данной статьи была оченка влияния использования гаджетов на формирование болевого синдрома в шее и плечах, а также головной боли среди учащчихя высших учебных заведений. В исследовании участвовали 90 респондентов, из них 60 женского пола и 30 мужского пола, возраст участников от 18 до 28 лет. С помощью самостоятельно созданного опросника в Gооgle dосs были оценены симптомы так называемой компьютерной шеи, такие как головная боль, боль/дискомфорт в шее и плечах, а также осведомленность о данном феномене. Исследование показало превалирование такого симптома, как боль/дискомфорт в плечах среди респондентов, 59 (66\%) участников беспокоил этот симптом с таким распределением по полу: 46 женщин (76\%) и 13 мужчин (43\%). Головную боль отметили 56\% участников и 50\% беспокоила боль/дискомфорт в шее. Среднее время использования телефона составило 5,3 часа. Было определено среднее время использования телефона, которое составило 5,3 часа. Было показано превалирование среди респондентов такого симптома как боль/дискомфорт в плечах (66\%), головная боль в той или иной степени беспокоила 56\% респондентов, отметили 50\% участников. Только треть (32\%) респондентов связывали свои симптомы с использованием гаджетов, то есть исследование продемонстрировало низкую осведомленность о данном синдроме среди студентов. Молодье люди не осознают негативное воздействия гаджетов на состояние здоровья, в частности, на состояние костно-мышечной системы. Принимая во внимание вынесказанное, авторы считают необходимым использовать комплексный подход с участием семьи, образовательных учреждений и здравоохранения в предотвращении развития данного синдрома, а также включить в учебные программы курс для ознакомления студентов с возможными негативными последствиями чрезмерного использования гаджетов на их здоровье.

Ключевые слова: студенты, компьютерная шея, неправильная осанка

\section{Информация об авторах}

Николенко Евгений Яковлевич, д. мед. н., проф., зав. кафедры общей практики семейной медицины медицинского факультета Харьковского национального университета имени В. Н. Каразина, пл. Свободы, 6, Харков, Украина, 61022

e-mail: e.nikolenko@karazin.ua https://orcid.org/0000-0002-7653-0644

\author{
Адамович Ирина Валерьевна, \\ ассистент кафедры общей практики \\ семейной медицины медицинского \\ факультета Харьковского \\ национального университета \\ имени В. Н. Каразина, пл. Свободы, 6, \\ Харков, Украина, 61022 \\ e-mail: i.adamovich@karazin.ua \\ https://orcid.org/0000-0002-8934-7291
}

Вовк Кира Витальевна, к. мед. н., доц. кафедры общей практики-семейной медицины медицинского факультета Харьковского национального университета имени В. Н. Каразина, пл.Свободы, 6, Харков, Украина, 61022 e-mail: ivovkkira1970@gmail.com https://orcid.org/0000-0003-2971-0842

Conflicts of interest: author has no conflict of interest to declare.

Конфлікт інтересів: відсутній.

Конфликт интересов: отсутствует. 